\title{
Motives for Practicing Active Sport Tourism by Students of Tourism and Recreation Degree Course
}

Jarosław Cholewa, Rajmund Tomik, Miłosz Witkowski, Bogusława Hawryluk

To Link this Article: http://dx.doi.org/10.6007/IJARBSS/v8-i7/4389

DOI: $\quad 10.6007 /$ IJARBSS/v8-i7/4389

Received: 28 May 2018, Revised: 15 June 2018, Accepted: 29 June 2018

Published Online: 18 July 2018

In-Text Citation: (Cholewa, Tomik, Witkowski, \& Hawryluk, 2018)

To Cite this Article: Cholewa, J., Tomik, R., Witkowski, M., \& Hawryluk, B. (2018). Motives for Practicing Active Sport Tourism by Students of Tourism and Recreation Degree Course. International Journal of Academic Research in Business and Social Sciences, 8(7), 481-489.

\section{Copyright: @ 2018 The Author(s)}

Published by Human Resource Management Academic Research Society (www.hrmars.com)

This article is published under the Creative Commons Attribution (CC BY 4.0) license. Anyone may reproduce, distribute, translate and create derivative works of this article (for both commercial and non-commercial purposes), subject to full attribution to the original publication and authors. The full terms of this license may be seen at: http://creativecommons.org/licences/by/4.0/legalcode

Vol. 8, No. 7, July 2018, Pg. 481 - 489 


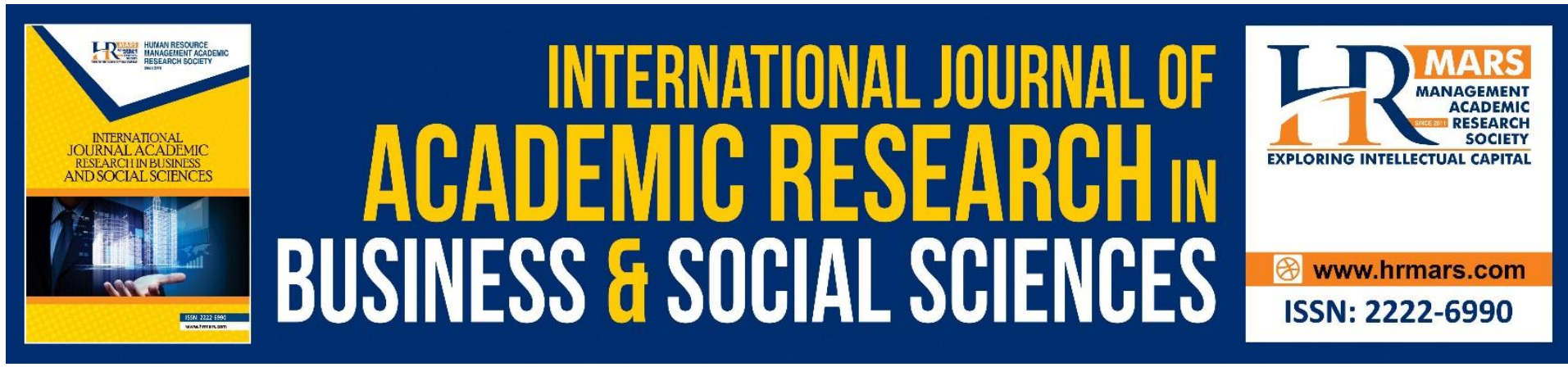

\title{
Motives for practicing active sport tourism by students of tourism and recreation degree course
}

\author{
${ }^{1}$ Jarosław Cholewa, ${ }^{1}$ Rajmund Tomik, ${ }^{2}$ Miłosz Witkowski, \\ ${ }^{1}$ Bogusława Hawryluk \\ ${ }^{1}$ Department of Physical Education, Department of Tourism and Health-Related Physical \\ Activity, The Jerzy Kukuczka Academy of Physical Education in Katowice, POLAND, ${ }^{2}$ \\ Department of Physical Education, State Higher Vocational School, Raciborz, POLAND
}

\begin{abstract}
Introduction: The decisions made by tourists, connected with the trip outside the place of residence as well as choice of destination are related to fulfilling different types of needs. Research of the motives of undertaking tourist activity were conducted to a different extent as well as in different parts of the population so far, however there are no reports concerning the motives of practicing active sport tourism by students of tourism and recreation studies, people who in the future will be organizing the leisure and holiday. Aim: The aim of this work was to present the motives of practicing active sport tourism by students of tourism and recreation course. Materials and Methods: The study involved 484 people, including 200 women (55.7\%) and 159 men (44.3\%). The method of diagnostic survey was implemented. The questionnaire consisted of four parts: personal details and 10 questions relating to participation in physical recreation for all respondents. Five questions concerning forms and the organization of practicing active sport tourism were also formulated for people who declared participation in that kind of tourism. Moreover, 49 statements were conveyed regarding the motives of involvement in active tourism to which the respondents answered according to the 5-step "Likert Scale". Results: Based on the survey and analysis of the literature it can be concluded that the most important role in making decisions about practicing active tourism among the surveyed students of tourism and recreation degree course were social factors: inclination for an active leisure with friends, the need for human contact and the health benefits of active sport tourism.
\end{abstract}

Keywords: Active Sport Tourism, Students, Tourism Motivation

\section{Introduction}

Tourism is an important and new sphere of economic activity and, at the same time, the sphere of social activity. Tourist activity is one of the measures of standard of living and an indicator of the civilizational development of societies. The development of tourism is an important factor boosting socio-economic development of the country. Its importance is reflected in the high capacity to generate new jobs, to improve the quality of life of local communities, to increase the competitiveness of the regions. Simultaneously, tourism 
contributes to dicovering the most valuable cultural and environmental resources, which, while exposed, improve the inland and outland image of the country, regions and villages. The right approach

to the development of tourism functions promotes maintaining traditional values and

sustainable development through drawing attention of the local communities to the most important natural and cultural assets.

The decisions made by tourists, connected with the trip outside the place of residence as well as choice of destination are related to fulfilling different types of needs. According to the traditional notion of A. Maslow, only after fulfilling basic needs, such as physiological needs and safety needs, followed by love and belonging and esteem needs, human strives for fulfilment of self-actualization need. It could occur during holiday, weekend or day-trips (Tesone, 2008). When taking a decision connected with travelling in the spare time, the man is guided by motives of various intensity. Their mutual interaction generates an individual's behaviour (Bowen and Clarke, 2009).

Research of the motives of undertaking tourist activity were conducted to a different extent as well as in different parts of the population so far. Studies have shown that the dominant motives were as follows: amusement, good value for money (Andreu et al,. 2005; Dejtisak et al., 2009), encountering different cultures, experiencing an adventure (Chadee and Cutler, 1996), relaxation and willingness to visit cultural and historical attractions (Jonsson and Devonish, 2008; Jiajia et al., 2009), rest and adventure (Kima et al., 2007). The motives of practicing active sport tourism were not distinguished in the research presented in the literature.

Characteristic feature of active sport tourism is travelling with the aim of practicing various kinds of sports. In literature Active Sport Tourism, along with Event Sport Tourism and Nostalgia Sport Tourism, is treated as part of Sport Tourism. Being physically active is a primary goal of the trip (Gibson, 1998). By defining this type of tourism, some authors emphasize that it refers to active participation in sport by tourists during the holidays (De Knop 1990). Academic studies of the active sports tourism are relatively few. Noteworthy are the theoretical deliberations of H. Gibson (1998) and T. Hinch, J. Higham (2011) and the characteristics of participants in this form of tourism carried out by De Knopp (1990). From the research we can conclude that people involved in active sport tourism are with good health, financially secure, satisfied with their position in life, relatively wealthy, welleducated, mostly men, with higher education, at the age of 18-44.

There are no reports in the literature concerning the motives of practicing active sport tourism by the students, particularly by the students of tourism and recreation studies, people who in the future will be organizing the leisure and holiday. Therefore the aim of this work is to present the motives of practicing active sport tourism by students of tourism and recreation course.

\section{Methodology}

The research included students of full-time and part-time as well as first-cycle and second-cycle studies of the Tourism and Recreation degree course at the Jerzy Kukuczka Academy of Physical Education in Katowice. The study involved 484 people, including 200 women (55.7\%) and 159 men (44.3\%). The method of diagnostic survey was implemented. The research tool was an anonymous questionnaire that students voluntarily completed. It 
was generated on a Google server, in the documents application, which enables the creation of an electronic version of this type of tools. The introduction included instructions to follow when completing the survey and the explanation how to interpret the term "active sport tourism". The survey consisted of four parts: personal details and 10 questions relating to participation in physical recreation for all respondents. Five questions concerning forms and the organization of practicing active sport tourism were also formulated for people who declared participation in that kind of tourism. Moreover, 49 statements were conveyed regarding the motives of involvement in active tourism to which the respondents answered according to the 5-step "Likert Scale". This paper analyzes the last part of the questionnaire "Motives for active sport tourism" (Różycki and Winiarski, 2005).

The structure of motivations for active recreational behavior consisted of seven motivational dispositions: Active, Cathartic, Health, Emotional, Social, Ambitious, Cognitive,

Seven questions related to each of these motivational dispositions respectively (including reverse ones). This allowed to calculate the index number of each disposition (quotient of the sum of points for each answer and the number 7), which ranged from 0-4. The index of number 2 corresponds to the answer "I do not know" and was interpreted as a neutral motivation in terms of the presented disposition. Higher scores signified increased motivation, and lower proved the respondent's increased lack of acceptance of at the disposition of a given type. which ranged from 0-4. The index of number 2 corresponds to the answer "I do not know" and was interpreted as a neutral motivation in terms of the presented disposition. Higher scores signified increased motivation, and lower proved the respondent's increased lack of acceptance of at the disposition of a given type.

Accuracy of the survey was determined by the assessment of competent judges. Reliability of the questionnaire was tested using Cronbach's alpha coefficient. Obtained Alpha values indicated the high internal consistency of the research tool $\alpha=0.87$ for the whole questionnaire, $\alpha=0,64-0,86$ for separate indexes.

In order to determine diversity between different types of motivational dispositions based on sex, analysis of variance and repeated measure was used twice. The factor that repeated was the type of motivational disposition. Significant result of the tests was set at $p$ $<0.05$.

\section{Results}

Research has shown significant alterations in the various types of motivational dispositions (Table 1). It applied to both women and men. For both groups of respondents the social factors were the most important while making the decision concerning active sport tourism.

Among them were distinguished: inclination for active holiday with friends, the need for human interaction.

The students also emphasized the health benefits of active sport tourism as significant factors influencing the willingness to take this form of spending free time. Within this index, the most supported was the following statement "The need to improve and maintain my health is very important reason for practicing active sport tourism". The least significant are the ambitious motives. Respondents did not accept such factors as impressing friends with practicing active sport tourism and the popularity of the place.

Thorough statistical analysis (post hoc test results) revealed that the social and ambitious motivational disposition indexes varied considerably from all the other indexes, both among women and men. 
The sex of respondents significantly diversified two of the seven indexes. The necessity to be physically active (active motivational disposition) and social factors were more important among women than men who make decisions about participation in active sport tourism. Statistical analysis of the other dispositions did not show any significant dimorphous differentiation.

\section{Discussion}

According to Decrop (2005) the answer to the question about the motives for the specific behaviour is the most essential element in understanding the complex process of holiday travel decision-making. Dejtisak et al. (2009) compared the motives of U.S. and international students in travelling using a survey consisting of 39 push factors and 27 pull factors. He stated that the main motives included amusement and visiting and experiencing new places (ratio over 4.3), whereas external factors comprised of good value for money, beautiful views and landscapes, safety and security (ratios of approximately 3.9). Although it was a specific group of respondents, similarly to the conducted research in this paper, motivations related to the beautiful nature experience and good value for money were also dominant.

A similar methodology was applied in the research of tourists coming to Jordan from different countries, however the results are definitely different. In this research, the dominant push factors were: visiting a place where I have not been, experience a new, different lifestyle and traditions as well as the possibility to see the environment (ratios of a little more than 4). By far the most important factor attracting those tourists was the willingness to see Petra, one of the seven wonders of the modern world (4.39) (Mohammad and Som, 2010).

In studies of tourists visiting Greece in the summer months the dominant types of tourists were "lovers of the sun", "escaping day-to-day life " "anthropologists" and "archaeologists" (Yfantidou et al., 2011). Although most types of tourists reveal specific motives corresponding to the tourist attractions in Greece, similarly to the research conducted in this work, the escapist motives were significant for travelling. Manel and Isoachol (1987) define them as an escape from the interpersonal relationships, personal problems and everyday life. 
INTERNATIONAL JOURNAL OF ACADEMIC RESEARCH IN BUSINESS AND SOCIAL SCIENCES Vol. 8, No. 7, July 2018, E-ISSN: 2222-6990 @ 2018 HRMARS

Table 1. The index values of motivational dispositions and their diversity

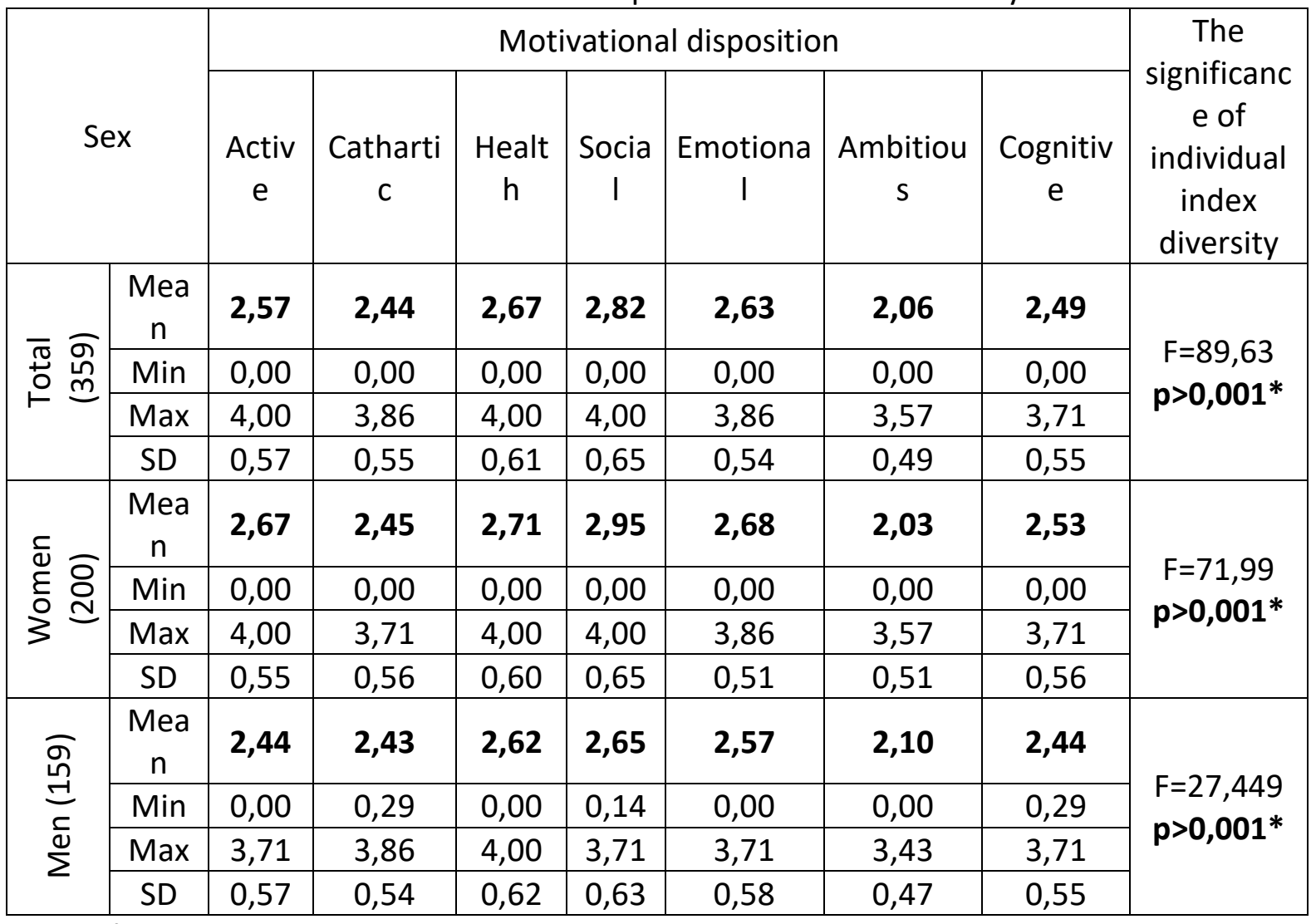

* Statistically significant differences

Table 2. The diversity of motivational disposition indexes based on sex

\begin{tabular}{|l|c|c|c|c|c|c|c|}
\hline \multirow{2}{*}{ Sex } & \multicolumn{7}{|c|}{ Motivational disposition } \\
\cline { 2 - 8 } & Active & $\begin{array}{c}\text { Catharti } \\
\text { C }\end{array}$ & Health & Social & $\begin{array}{c}\text { Emotion } \\
\text { al }\end{array}$ & $\begin{array}{c}\text { Ambitio } \\
\text { us }\end{array}$ & $\begin{array}{c}\text { Cognitiv } \\
\text { e }\end{array}$ \\
\hline Total (359) & 2,57 & 2,44 & 2,67 & 2,82 & 2,63 & 2,06 & 2,49 \\
\hline Women (200) & 2,67 & 2,45 & 2,71 & 2,95 & 2,68 & 2,03 & 2,53 \\
\hline Men (159) & 2,44 & 2,43 & 2,62 & 2,65 & 2,57 & 2,10 & 2,44 \\
\hline $\begin{array}{l}\text { The } \\
\text { significance of } \\
\text { index diversity } \\
\text { based on sex }\end{array}$ & $\begin{array}{c}\mathbf{F}=\mathbf{1 4 , 8 2} \\
\mathbf{7}>\mathbf{0 , 0 0 1} \\
*\end{array}$ & $\begin{array}{c}\mathrm{F}=0,107 \\
\mathrm{p}=0,744\end{array}$ & $\begin{array}{c}\mathrm{F}=1,783 \\
\mathrm{p}=0,183\end{array}$ & $\begin{array}{c}\mathbf{F}=\mathbf{1 8 , 9 3} \\
\mathbf{6}>\mathbf{0 , 0 0 1} \\
*\end{array}$ & $\begin{array}{c}\mathrm{F}=3,713 \\
\mathrm{p}=0,055\end{array}$ & $\begin{array}{c}\mathrm{F}=1,523 \\
\mathrm{p}=0,218\end{array}$ & $\begin{array}{c}\mathrm{F}=2,357 \\
\mathrm{p}=0,126\end{array}$ \\
\hline
\end{tabular}

* Statistically significant differences 
INTERNATIONAL JOURNAL OF ACADEMIC RESEARCH IN BUSINESS AND SOCIAL SCIENCES Vol. 8, No. 7, July 2018, E-ISSN: 2222-6990 @ 2018 HRMARS

The same motives were also prevailing for American female students responding to online survey (Kim and Beck, 2009). On the other hand, for German and British tourists spending their holidays in Turkey and Mallorca the relaxation was the main push factor, and the weather was the pull factor (Koza 2002). Jonsson and Devonish (2008) used the same methodology and questioned people resting in hotels in Barbados, and they also pointed to relax and emotional and physical refreshment, as the main motive for travelling.

It can be concluded from the presented data in the literature that tourist attractions of the given place play an important role as one of the main factors determining the choice of the travel direction by tourists. These results were not confirmed in the research conducted with students. Students are characterized by different requirements in relation to the services provided. For this social group amusement, good value for money (Dejtisak et al., 2009), encountering other cultures, experiencing an adventure (Chadee and Cutler, 1996), relaxation, rest and adventure (Kima et al., 2007) are essential. In case of tourist offers addressed to students, the specific needs by that group should be taken into account like offering new experiences, an accessible price of the service and affordable accommodation (Slabbert et al. 2012, Rafalska et al., 2018). The results concerning the motives for practicing active sport tourism obtained in the work did not differ from the intentions of tourist trips in the group of students. On this basis it can be concluded that the type of tourism activity does not differentiate significantly the motives for tourist trips in the group of students.

As a result of increased competition among companies and tourist regions, appropriate marketing activities (based on the previous research concerning visitiors) are crucial. Such activities in active tourism should be based on efficient combination of relevant marketing tools within the marketing mix strategy - 4P (product, price, promotion, place). This type of tourism is used in most voivodships in Poland to increase tourist traffic. Products based on active tourism can be offered both to the inhabitants of the region (especially in the urbanized areas) who are interested in the weekend trips or even one-day outdoor leisure acivites, and to people from other regions. In most of the voivodships, local natural values and places particularly attractive for tourists who prefer active leisure time are promoted. In such marketing activities only pull factors are used, while the push factors are omitted.

Knowledge of motives influencing travel decisions gives the opportunity to increase the effectiveness of promotional campaigns for both tourist products and local government strategies informing about the tourist attractions of a particular region. Social and health motives are important for the study population. Other factors will probably affect the participation of another social group in active tourism. During preparation for a marketing campaign of regions and tourism businesses, which is addressed to a specific group of consumers, the factors that influence the choices of tourists could be highlighted. A similar conclusion was reached by Niemczyk (2012), who studied the motives of cultural tourism participants. It concludes that the motives of participation in cultural tourism differentiate tourists' proceedings concerning the cultural trips. As a result, it highlights the usefulness of the above-mentioned content for the tourist industry as well as the representatives of local government units participating in the creation of the tourism product of the region. The conclusions from the analysis can be used in practice for the organization of a cultural policy in the city, especially with regard to tourists as its recipients (Niemczyk, 2012).

Berbeka (2003) who studied the factors affecting consumer behaviour in the sports market, mentioned the motivation among the psychological factors. She claimed that the range of needs satisfied by the sports activity can be very broad and it is the mission of the marketing to make potential clients aware of certain needs, shaping and arousing them. In order to arouse, shape and 
INTERNATIONAL JOURNAL OF ACADEMIC RESEARCH IN BUSINESS AND SOCIAL SCIENCES

Vol. 8, No. 7, July 2018, E-ISSN: 2222-6990 @ 2018 HRMARS

satisfy the needs, they ought to be known, therefore studied. Motivation that stimulates and directs human behavior is the result of unsatisfied needs.

\section{Conclusion}

Based on the survey and analysis of the literature it can be concluded that:

1. The most important role in making decisions about practicing active tourism among the students of tourism and recreation degree course were social factors: inclination for an active leisure with friends, the need for human contact and the health benefits;

2. Type of tourist activity does not differentiate significantly the students in terms of motives.

\section{References}

Andreu, L., Koza, M., Avci, N., Cifter, N. (2005). Market Segmentation by Motivations to Travel: British Tourists Visiting Turkey. Journal of Travel and Tourism Marketing, 19, 1, 1-14.

Berbeka J. (2003). Factors affecting consumer behavior on the sports market. Marketing and Market, 5, 23-29.

Bowen, D., Clarke, J. (2009). Contemporary tourist behavior: Yourself and others as tourist. CABI Publishing International.

Chadee, D., Cutler, J. (1996). Insights into international travel by students. Journal of Travel Research, 35, 75-80.

De Knop, P. (1990). Sport for all and active tourism. World Leisure and Recreation, 32, 30-36. Decrop, A. (2005). Group Processes in Vacation Decision-Making. Journal of Travel \& Tourism Marketing, 18, 3. 23-36.

Dejtisak, M., Hurd, A.R., Elkins, D.J., Schlatter, B.E. (2009). A Comparison of Travel Decisions Between U.S. and International Students. LARNet; The Cyber Journal of Applied Leisure and Recreation Research, January pp.unpaginated ref.25.

Gibson, H. (1998). Active sport tourism: who participates? Leisure Studies, 17, 155-170.

Gibson, H. (1998). Sport Tourism: A Critical Analysis of Research. Sport Management Review, 1, 4576.

Hinch, T., Higham, T. (2011). Sport Tourism Development, Channel View Publications, Bristol, Bufflo, Toronto.

Jiajia, W., Jing, X., Erdogan, E. (2009). Investigating the Push and Pull Motivation of Visiting Domestic Destination in China: A Means-End Approach. Journal of China Tourism Research, 5, 287-315.

Jonsson, C., Devonish, D. (2008). Does Nationality, Gender, And Age Affect Travel Motivation? A Case of Visitors To The Caribbean Island of Barbados. Journal of Travel \& Tourism Marketing, 25, 3-4, 398-408.

Kim, K., Beck J.A. (2009). Exploring Leisure Trip Behaviors of University Women Students: An Investigation of Push and Pull Motivational Models. Journal of Hospitality Marketing \& Management, 18, 386-405.

Kima, K., Nohb, J., Jogaratnam, G. (2007). Multi-Destination Segmentation Based on Push and Pull Motives. Journal of Travel \& Tourism Marketing, 21, 2007, 19-32.

Koza, M. (2002). Comparative analysis of tourist motivations by nationality and destinations. Tourism Management, 23, 221-232.

Mannell, R., Iso-Ahola, S. (1987). Psychological Nature of Leisure and Tourism Experience. Annals of Tourism Research, 14, 314-331. 
INTERNATIONAL JOURNAL OF ACADEMIC RESEARCH IN BUSINESS AND SOCIAL SCIENCES

Vol. 8, No. 7, July 2018, E-ISSN: 2222-6990 (C) 2018 HRMARS

Marcus, B.H., Forsyth, L.H. (2003). Motivating People to Be Physically Active. Human Kinetics, Champaign, IL.

Mohammad, B.A.M.A., Som, A.P.M. (2010). An Analysis of Push and Pull Travel Motivations of Foreign Tourists to Jordan. International Journal of Business and Management, 5, 12, 41-50.

Niemczyk, A. (2012). Motives as a determinant of cultural tourism participants. In: Challenges of contemporary tourism policy. Problems of functioning of the tourist market, edited by A. Rapacz, Wroclaw University of Economics No. 258, 47-57.

Rafalska, B., Cholewa, J., Tomik, R. (2018). Factors Determining Kayak Tourism in the Silesian Province. Folia Turistica, 45, 64-77.

Rózycki, P., Winiarski, R. 2005, Social Factors influencing Tourist Activity among Youths, Tourism Review, 60, 1, 20-25.

Slabbert, E., Saayman, M., Van Der Merwe, P. (2012). Travel behaviour of south african tourism students. South African Journal for Research in Sport, Physical Education \& Recreation, 34, 1, 137-151.

Tesone, D. (2008). An Interdisciplinary Study of Motivation Theories used by Tourism Management Practitioners. Journal of Tourism, IX, 2, 209-220.

Yfantidou, G., Costa, G., Michalopoulou, M. (2011). Human needs determining the profiles of popular tourist roles in Greece. Studies in Physical Culture and Tourism, 18, 1, 59-70. 